\title{
7. MESOZOIC EVOLUTION OF ORTEGAL SPUR, NORTH GALICIA MARGIN: COMPARISON WITH ADJACENT MARGINS ${ }^{1}$
}

\author{
Gilbert Boillot, ${ }^{2}$ Jacques-André Malod, ${ }^{3}$ \\ Pierre-Alain Dupeuble, ${ }^{4}$ and CYBERE Group ${ }^{5}$
}

\begin{abstract}
Ortegal Spur (north Galicia margin, Spain) was surveyed by the French submersible Cyana and by dredging. About 110 rock samples were taken to establish the Mesozoic and Cenozoic stratigraphy and evolution, and the structural pattern was observed from the submersible. Resting directly on the basement rock, the Middle and Upper Jurassic carbonate platform was broken and capped by sandy sediments during the Early Cretaceous. The age of the post-rift unconformity is pre-Albian, as on adjacent margins. The $\mathrm{N} 70^{\circ}$ orientation of the Mesozoic rift was oblique with respect to west Galicia and north Spanish rifts. Subsidence rates during the Mesozoic remained low and resulted in a thin sedimentary cover deposited in shelf or slope environments. Finally, the Mesozoic structures were reactivated and hidden when the Cretaceous passive margin became an active margin during the Paleocene and Eocene.
\end{abstract}

\section{INTRODUCTION}

Ortegal Spur is at the northwest corner of the Iberian Peninsula, approximatively $400 \mathrm{~km}$ northeast of Galicia margin, drilled during ODP Leg 103 (Fig. 1). The spur was part of a continental rift during the Late Jurassic and Early Cretaceous and became a passive margin during the Late Cretaceous. Structures resulting from rifting were reactivated during the Cenozoic convergence of the Eurasian and Iberian plates (Fig. 2). This convergence resulted in partial subduction of the Bay of Biscay (Eurasian plate) beneath Iberia, as indicated by a buried trench and a tectonic accretionary prism at the foot of the north Spanish slope (Sibuet and Le Pichon, 1971; Deregnaucourt and Boillot, 1982; Grimaud et al., 1982). Related to this subduction, shortening, folding, and erosion of the north Spanish margin have exposed basement and Mesozoic rocks on the slope. These conditions make this margin favorable for sampling by dredging or for direct observation using a submersible.

We conducted two cruises in the Ortegal Spur area. The first, in 1980 , was a site survey with Sea Beam mapping (Vanney et al., 1985) to prepare for the second cruise in 1982 with the manned submersible Cyana (Cybere cruise). Dive sites were selected at tectonic escarpments or in gullies on the slope (Fig. 3). Onehundred rock samples, including basement rocks, were recovered during 14 dives. In addition, about 100 other samples from 9 dredge hauls where collected from cliffs at water depths greater than $3000 \mathrm{~m}$, beyond the capabilities of Cyana (Groupe Cybere, 1984; Temime, 1984; Boillot et al., 1985). The sedimentary rocks collected (about 110 samples) compose a fairly good sampling of the Mesozoic and Cenozoic sequence, which can be used as a stratigraphic reference for the rest of the Iberian Atlantic margin.

This paper focuses on the Mesozoic evolution of Ortegal Spur. Sedimentary rocks collected from the Cybere cruise provide valu-

\footnotetext{
${ }^{1}$ Publication No. 352 of the Groupe d'Etude de la Marge Continentale, Université Pierre et Marie Curie, Paris, and CNRS UA 718.

2 Laboratoire de Géodynamique Sous-Marine, Centre de Recherche et d'Etude Oceanographique de Villefranche-sur-Mer, 06230-Villefranche-sur-Mer (France)

${ }^{3}$ Département de Géologie Dynamique, Université Pierre et Marie Curie, 75252 Paris, Cedex 05 (France).

${ }^{4}$ Laboratoire de Géologie, Université de Rouen, 76130 Mont-St.-Aignan (France).

5 R. Capdevila, M. Cousin, F. Gonzalez-Lodeiro, J. P. Herbin, M. Lamboy, C. Lepvrier, J. Martinez-Catalan, G. Mascle, C. Muller, L. Pastouret, F. Rojouan, J. Taugourdeau-Lantz, D. Temime, and J. R. Vanney.
}

able information for understanding Leg 103 drilling results presented in the site chapters (this volume). Structural data, on the other hand, provide information on the orientation of the Cretaceous passive margin and the former rift there.

\section{STRATIGRAPHY}

The Mesozoic to Holocene sedimentary cover of the northern Galicia margin is about $1300 \mathrm{~m}$ thick (Groupe Cybere, 1984). On the basis of observations and sampling data from the Cyana and dredge hauls, this cover can be divided into four sequences, separated by unconformities and/or distinguished by changes in sedimentary facies (Fig. 4).

\section{Dogger-Berriasian (400 m)}

Twenty-four rock samples from the Dogger-Berriasian sequence were collected during dives, and 23 additional samples were recovered by dredging. One sample of Dogger age was recovered-a limestone containing filaments, characterized by graded beds, and interpreted to have been deposited in a sedimentary basin of shallow or intermediate depth $(80-300 \mathrm{~m})$ (Fig. 5A). A dark limestone, which includes bryozoan remains (Fig. 5B) is probably Oxfordian in age, suggesting perireefal or outer-shelf conditions during that time. Kimmeridgian, Portlandian, and lowermost Cretaceous (Berriasian) carbonates crop out widely (Fig. 6A). They consist of platform limestones (wackestone to packstone, occasionally grainstone), locally sandy (Fig. 5D) or dolomitic, which were deposited at shallow depths, sometimes in the tidal zone. Some micritic limestones with calpionellids (Fig. 5C) suggest, at least locally, an open-sea pelagic influence.

\section{Berriasian-Aptian (300 m)}

About 30 rock samples belonging to the Berriasian-Aptian sequence were recovered from dredge hauls or by the submersible Cyana. The sequence conformably overlies the TithonianBerriasian carbonates. Rocks are principally sandy limestones, siltstones, and sandstones (Fig. 6B) containing quartz $(30 \%-$ $65 \%)$, feldspars $(25 \%-60 \%)$, and micas $(5 \%-35 \%)$. The coarse grain size of the quartz and feldspar grains and lithic clasts indicate that the material has not traveled far from its source. This is confirmed by the similarity between the mineralogy of the sediments and that of the basement rocks sampled in the same area (Groupe Cybere, 1984). The poor benthic foraminifera assemblage, as well as the plant debris content, suggests a shallow-water depositional environment (0-200 m). 


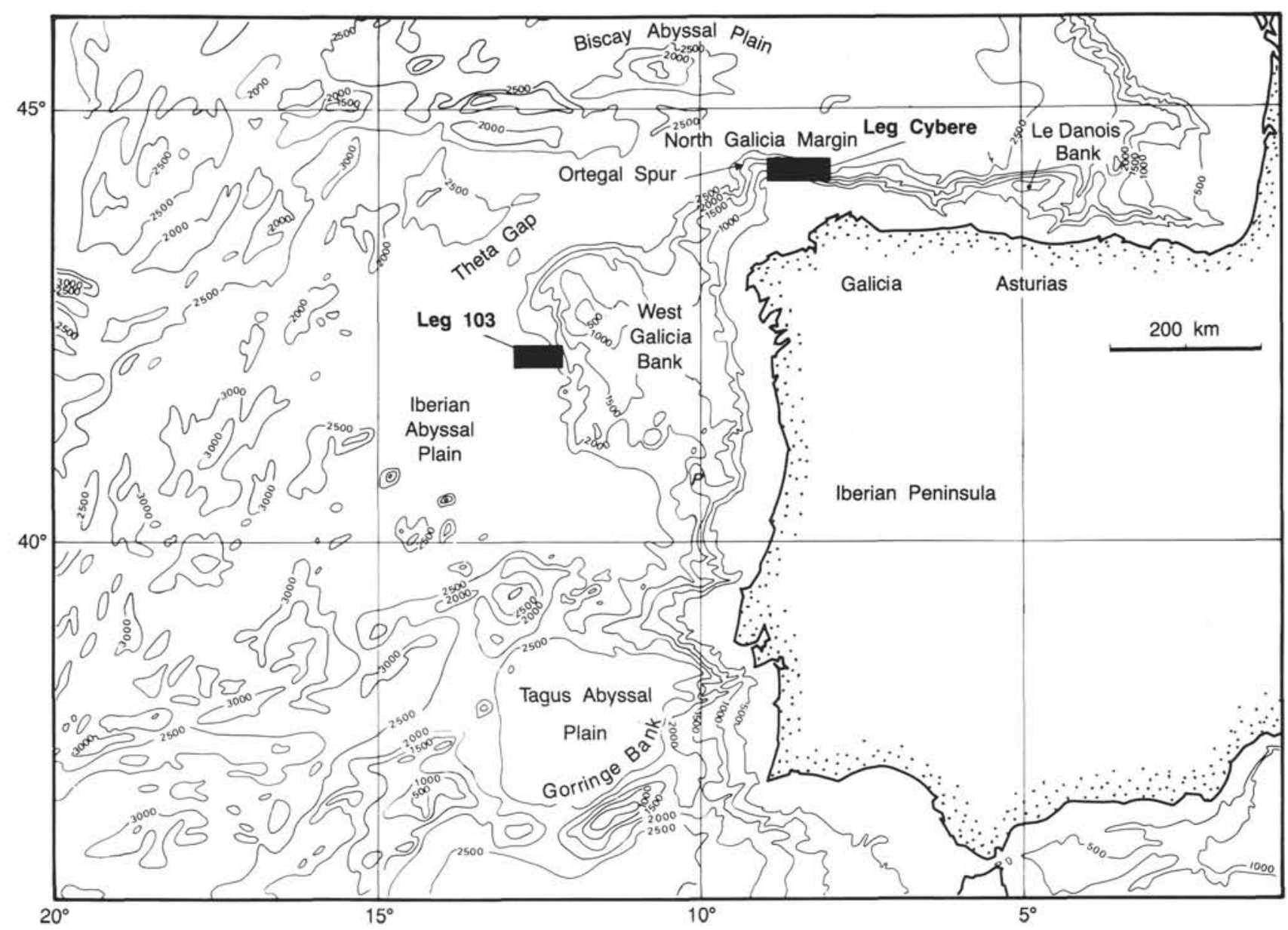

Figure 1. Location of Ortegal Spur margin (north Galicia margin) with respect to west Galicia margin. Location of Cybere cruise and ODP Leg 103 are shown. Bathymetric contours in meters.

\section{Late Aptian-Senonian (500 m)}

Twenty samples of the late Aptian-Senonian sequence were recovered during dredging or diving. The sequence is separated from the underlying rocks by an unconformity (the break-up unconformity; see following text). Late Aptian-early Albian samples are silty or fine-grained sandstone, rich in organic matter (plant debris), and closely resemble the black shales noted in other regions of the North Atlantic. However, most of the samples recovered are late Albian in age and consist of limestone, marlstone, and fine-grained sandstone. Sandy limestone contains rounded Orbitolina remains. The sequence also includes interbedded conglomerate. The micropaleontological assemblage and the sedimentological characteristics indicate that the sequence was deposited either on the shelf (Fig. 5E) or on the slope (Fig. $5 \mathrm{~F})$. This indicates a general subsidence of the margin since Aptian time. The uppermost part of the sequence consists of Senonian conglomerate, including boulders of Upper Jurassic or lowermost Cretaceous limestone, probably deposited within gullies or along steep slope scarps.

As shown on the geological cross section drawn from data from dives 79 and 80 at Site 3 (Fig. 7), these Albian to Senonian sediments lie unconformably on either the Hercynian basement or the Upper Jurassic-Lower Cretaceous material. This major pre-Albian unconformity is interpreted as being the break-up unconformity associated with the end of rifting and the begin- ning of oceanic crust spreading in the Bay of Biscay. Therefore, the underlying Dogger-Berriasian and Berriasian-Aptian sequences probably represent the pre- and syn-rift sediments of the margin, respectively. This interpretation is in agreement with the evolution of the conjugate Armorican margin and of the adjacent west Galicia margin, where the same break-up unconformity was drilled (Montadert et al., 1979; Sibuet, Ryan, et al., 1979; Site 641 chapter, this volume).

\section{Late Eocene to Holocene (100 m)}

Twelve samples of upper Eocene limestone were recovered, consisting of grainstone to packstone and sandstone, deposited in a shelf environment. Eocene limestone rests directly upon basement rock at the edge of the shelf. At greater depth on the slope, Eocene limestone overlies Mesozoic rocks. This indicates that the pre-Eocene unconformity, which was described on the nearby shelf (Lamboy and Dupeuble, 1975; Lamboy, 1976), also occurs on the slope. Pyrenean tectonics produced this second major unconformity, which is recognized along the entire north Spanish margin (Boillot et al., 1973, 1979). Eocene shelf sediments are now located between 700 and $2700 \mathrm{~m}$ water depth, indicating significant subsidence of the margin since the late Eocene.

Oligocene rocks were not recovered during the Cybere cruise. Moreover, Neogene silty marl and foraminiferal ooze, associated with slope breccias or conglomerates, indicate a relatively 


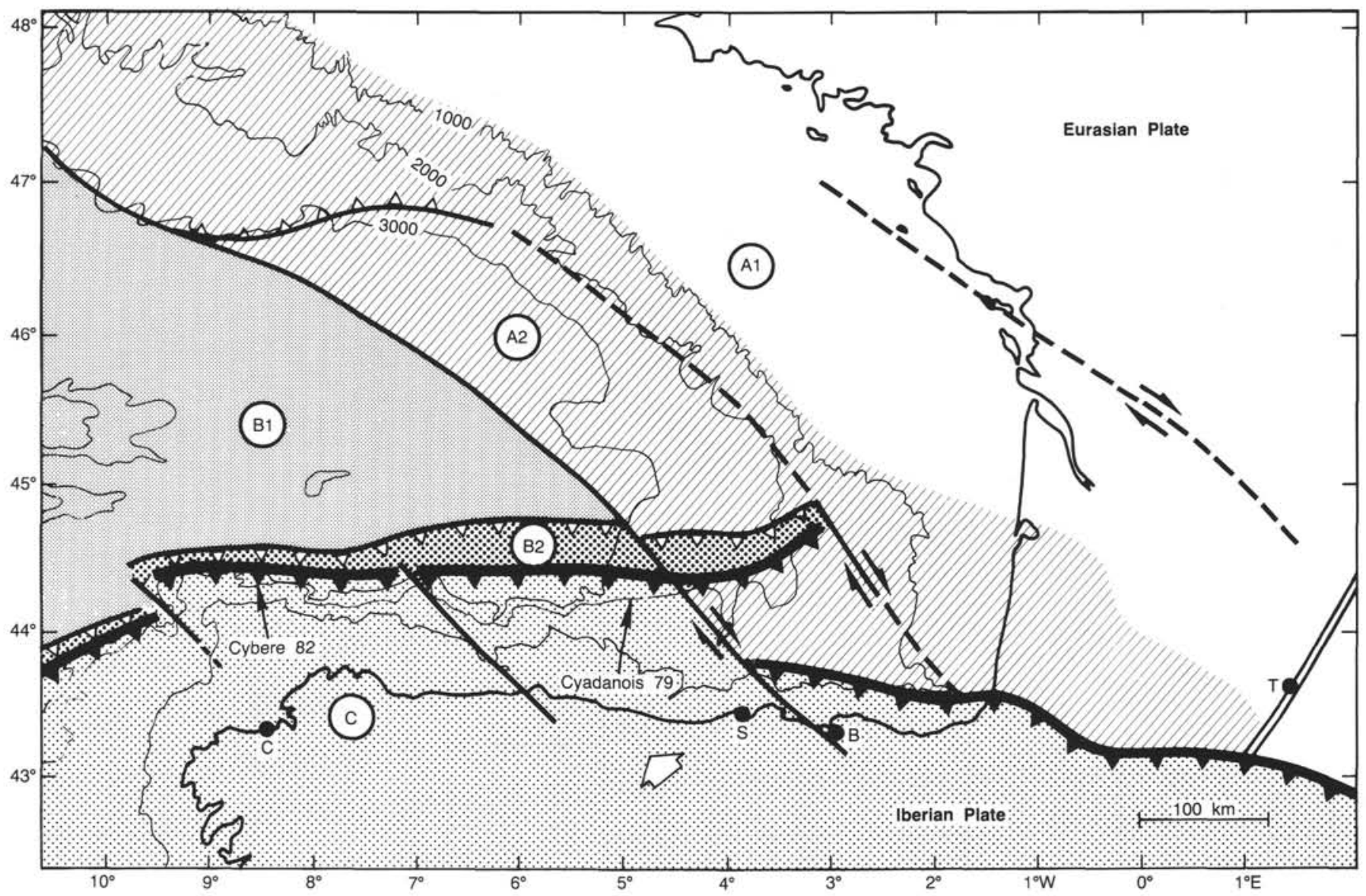

Figure 2. Structural diagram of the Bay of Biscay and location of areas studied during Cyadanois 1979 and Cybere 1982 cruises. A1 = normal continental crust; $\mathrm{A} 2$ = thinned continental crust; $\mathrm{B} 1=$ oceanic crust; $\mathrm{B} 2=$ tectonic accretionary prism, built up during Paleocene and Eocene at the Iberian-European converging-plate boundary; $\mathrm{C}=$ thickened continental crust, resulting from the plate convergence and from the southward subduction of the oceanic lithosphere beneath Iberia. White arrow shows direction of Iberian motion with respect to stable Europe. From Deregnaucourt and Boillot (1982).

deep-water depositional environment (probably 500-3000 m). The present morphology of the margin was, therefore, probably shaped during Oligocene time.

\section{THE MESOZOIC RIFT AND MARGIN}

The stratigraphy of the Mesozoic sedimentary cover, as evidenced by the Cybere cruise data, allows us to distinguish different phases related to rifting and spreading in the Bay of Biscay. However, because the Ortegal Spur area has always remained a shelf or slope environment, the facies contrasts are too small to reconstruct a specific paleogeography. Therefore, we instead attempted a structural and morphological approach to specify paleodirections of the Mesozoic rift and margin (Figs. 8 and 9).

On the slope above $2500 \mathrm{~m}$ water depth, main escarpments shown on the Sea Beam map follow the N50 $-\mathrm{N} 70^{\circ}$ direction (Fig. 9). These escarpments correspond to outcrops of basement rock and Jurassic-Lower Cretaceous limestone, which were observed in detail at Sites 2 and 3 of the Cybere survey. As shown previously (Fig. 7), Albian-Cenomanian marls at Site 3 overlie the basement rock on the upper part of the slope and the Mesozoic formations on the lower part. The geometric arrangement of basement and Mesozoic rocks indicates that they are necessarily separated by a fault, which was active before Albian, i.e., during rifting. This fault trends $\mathrm{N} 50^{\circ}$, as does the local morphology. At Site 2 (Fig. 8), the same directions are well constrained (Groupe Cybere, 1984). A major fault trending $\mathrm{N}_{50}^{\circ}$ -
$\mathrm{N} 70^{\circ}$ separates basement and Upper Jurassic-Lower Cretaceous limestones from Lower Cretaceous strata. We interpret these fractures to be normal faults of the rift, more or less reactivated during the Cenozoic.

The $\mathrm{N} 120-150^{\circ}$ faults also depicted in Figures 8 and 9 are hypothetical, inferred as having produced the offset of outcrops and $\mathrm{N} 50^{\circ}-\mathrm{N} 70^{\circ}$ faults, and interpreted as being possible transverse structures of the Early Cretaceous rift.

In conclusion, the main direction of the Mesozoic rift on that part of the Galicia margin is probably $\mathrm{N} 50^{\circ}-\mathrm{N} 70^{\circ}$, parallel to the present coastline but oblique with respect to the present slope (Fig. 9). Actually, the present morphology results from Pyrenean tectonics and not from Mesozoic rifting.

\section{COMPARISON WITH ADJACENT MARGINS}

\section{Comparison with West Galicia Margin (Leg 103 Area)}

Currently, physiography constitutes the main difference between the western and northern segments of Galicia margin. The northern margin is narrow and steep (less than $120-150 \mathrm{~km}$ from the coast to the abyssal plain), whereas the western margin is wide and gentle ( $300 \mathrm{~km}$ for the same transition). This contrast partly results from Cenozoic shortening and shaping of the north Galicia slope. However, according to plate tectonic models of the convergence between Iberia and Europe (Grimaud et al., 1982; Olivet et al., 1984), $150 \mathrm{~km}$ of horizontal shortening is un- 


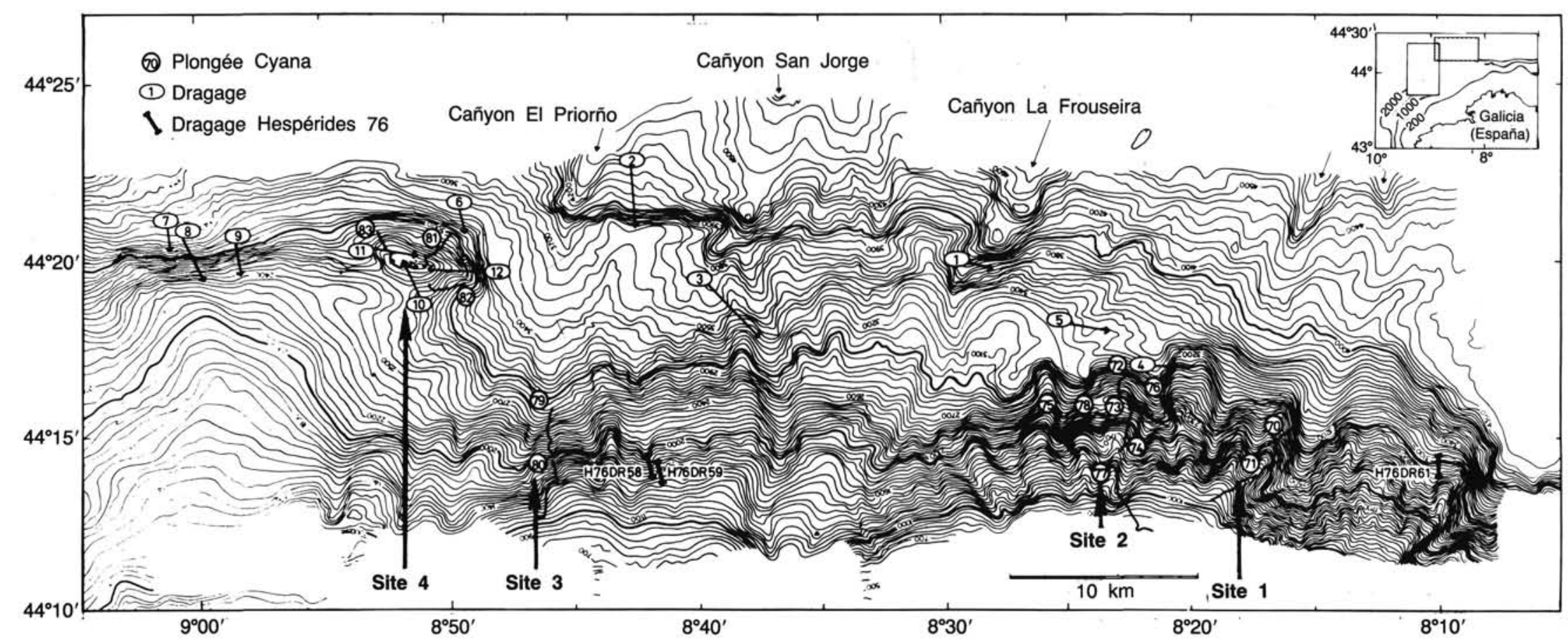

Figure 3. Sea Beam map with location of diving sites 1 through 4 of Cybere leg and dredge locations. Bathymetry from Vanney et al., 1985. 

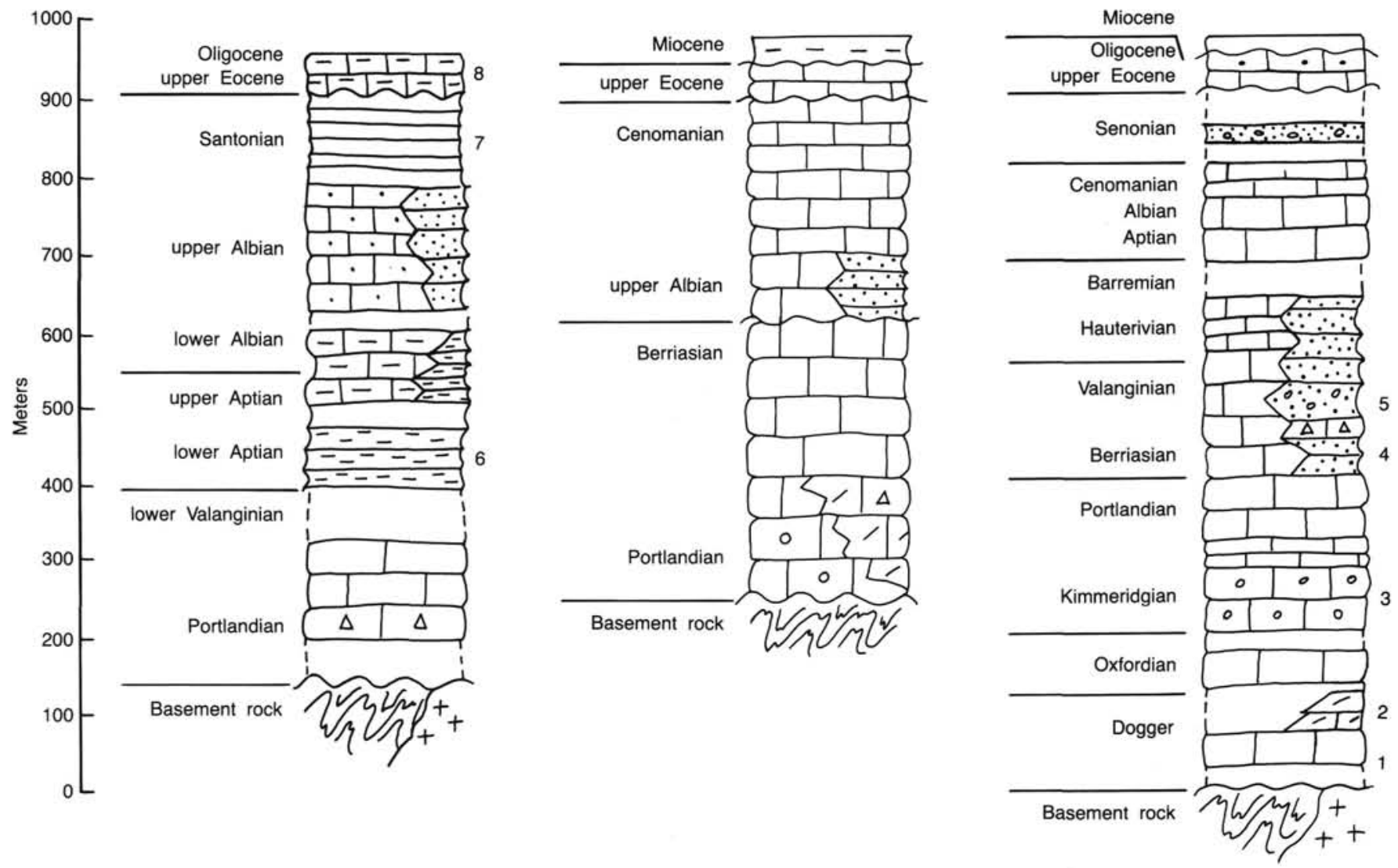

Figure 4. Stratigraphic $\log$ at sites 2,3 , and 4 of Ortegal Spur, derived from samples collected during dives and dredges. $1=$ massive limestone; 2 = dolomitic limestone; $3=$ brecciated and gravelly limestone; $4=$ sandstone; $5=$ coarse sandstone and conglomerate; $6=$ silt; $7=$ shale; $8=$ marly limestone. Site locations shown in Figure 3.

likely. Certainly, the physiography of the two margins was also different during the Late Cretaceous, even if the contrast was increased later by the Pyrenean tectonics.

The difference in orientation of these two margin segments is related to the difference in the strikes of the main Mesozoic normal faults, trending north-south on western Galicia margin (see "Introduction, Objectives, and Principal Results" chapter, this volume) and $\mathrm{N} 70^{\circ}$ on northern Galicia margin (Fig. 9). Likewise, probable transverse faults of the former rifts are oriented $\mathrm{N} 70^{\circ}$ and $\mathrm{N} 140^{\circ}-150^{\circ}$ on western Galicia (Boillot, 1986) and Ortegal Spur margins, respectively.

Another major difference concerns the facies of syn-rift deposits. From Valanginian time throughout the Early Cretaceous, the seafloor was probably at a great depth at the location of Site 638 (see Site 638 chapter, this volume), whereas the locations surveyed by Cyana on the Ortegal Spur probably remained shallow. We conclude that continental crust was significantly thinned below the western deep margin (Leg 103 area), whereas it was normal or poorly thinned below the Ortegal Spur slope.

\section{Comparison with the Asturian and Basque Margin (Northern Spain)}

To the east of Galicia, the direction of the Cretaceous margin is about $\mathrm{N} 120^{\circ}$, and rift structures following that direction are partly preserved in the Basque region (Rat et al., 1983; Wiedman et al., 1983). Such large faults as the Vidio fault northeast of Galicia (Lamboy, 1976), the Ventaniella fault in Asturias (Martinez-Albarez, 1974), and the Urbiena fault in the Cantabric chain
(Pujalte, 1981) also strike this direction. A N20 direction appears transverse to the rift and is evidenced in the Basque region (Feuillee and Rat, 1971).

Pre- and syn-rift sediments of the deep margin are exposed on the Asturian slope, where they were sampled during a detailed survey of the Le Danois Bank area (Cyadanois Leg, Fig. 2; Malod et al., 1980, 1982). The lower part (pre-rift) of the sedimentary sequence (Fig. 10) is similar to the Dogger-Berriasian sequence of Ortegal Spur. It consists of Kimmerigian to Portlandian limestones, overlain by massive and commonly dolomitized Tithonian limestones, all deposited in a shallow-marine environment. As in the Ortegal Spur area, the carbonate platform of Late Jurassic-earliest Cretaceous age was broken by Valanginian through Aptian rifting. However, the syn-rift facies are different on the Le Danois Bank and Ortegal Spur margins (Fig. 10). On the Asturian slope, Hauterivian turbidite-like sandstones rich in plant debris are capped by Barremian and Aptian siltstones similar to black shales. This Lower Cretaceous synrift sequence is thicker and was deposited in a deeper marine environment than were the same formations of the north Galicia slope. However, the sequence is similar to the Valanginian through Aptian syn-rift sequence drilled during Leg 103 (Sites 638-641 chapters, this volume).

\section{Timing of the Rifting}

The age of the post-rift unconformity on the Armorican margin (Montadert, Roberts, et al., 1979) and on the west Galicia margin (Sibuet, Ryan, et al., 1979; Site 641 chapter, this vol- 


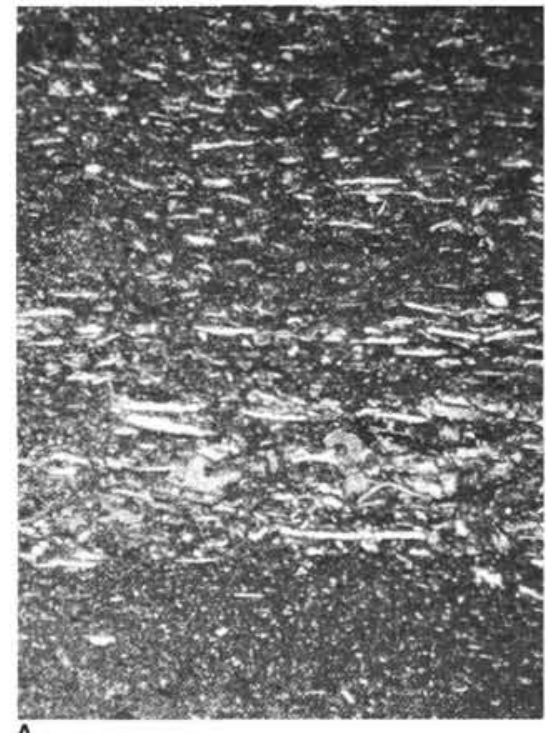

A

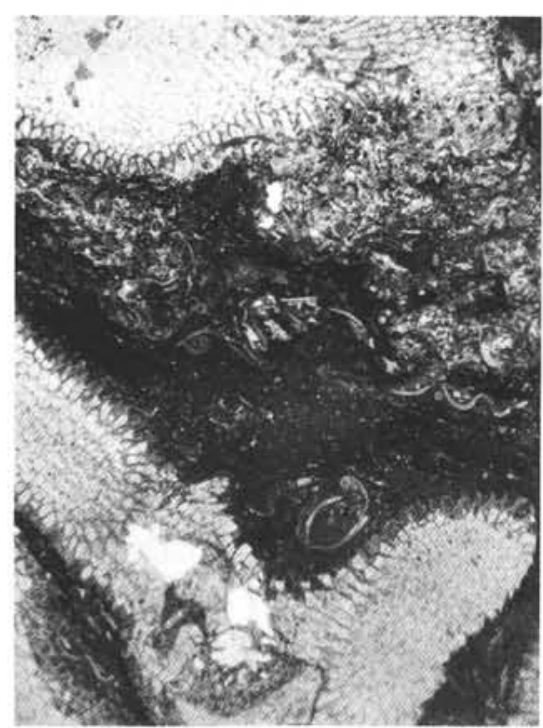

B

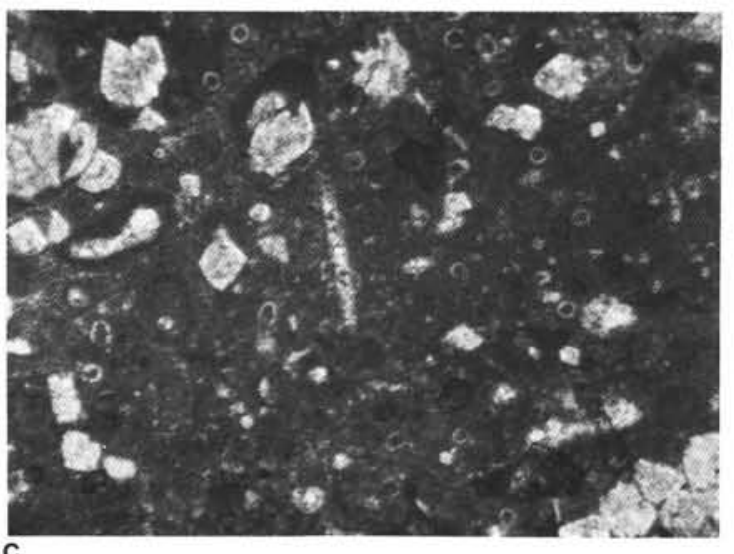

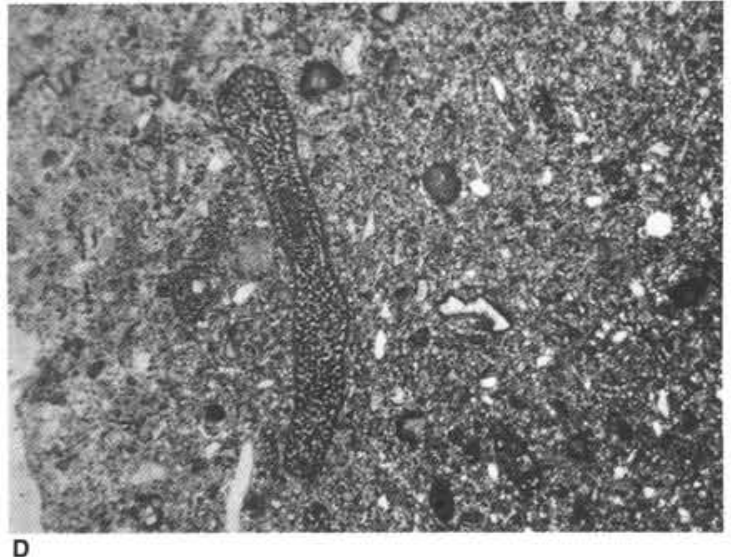

D

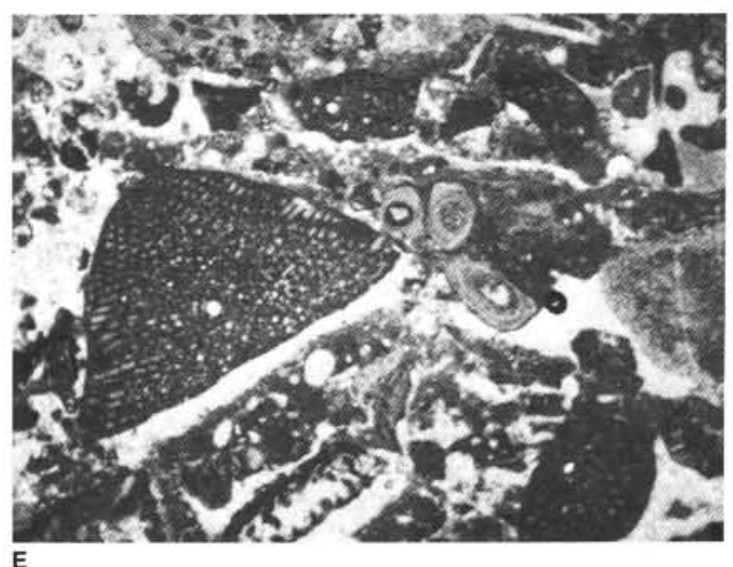

E

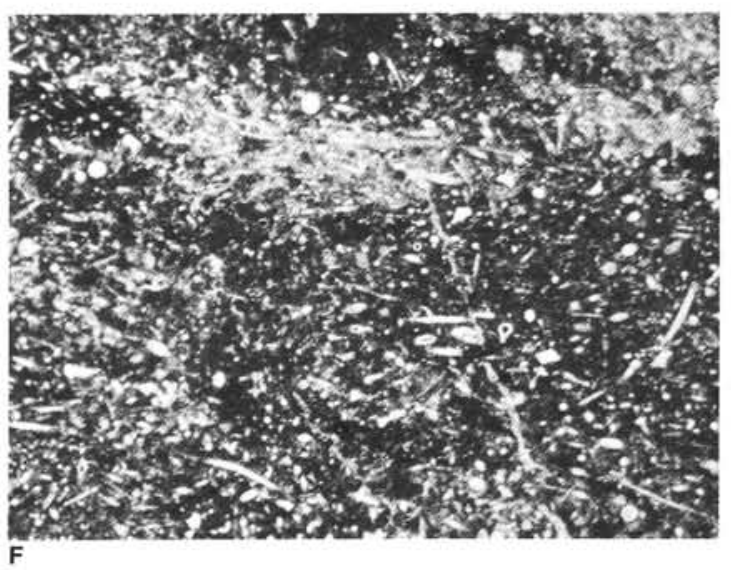

Figure 5. Microphotographs of Mesozoic sediments. (A) Limestone with filaments and some echinoid remains in graded beds, Dogger (sample 75 E 6, $\times 17$ ). (B) Limestone with bryozoans, likely Oxfordian, perireefal, or outer-shelf deposit (sample 74 E 6, ×6). (C) Dolomitized limestone with calpionellids: Calpionella alpina, Crassicolaria parvula(?), late TithonianBerriasian (sample DR $04 \mathrm{E} \mathrm{15}, \times 38$ ). (D) Bioclastic sandy and slightly micaceous limestone with Anchispirocyclina lusitani$c a$ and rare Lenticulina, Tithonian, platform deposit (sample 74 E 2, $\times 5$ ). (E) Bioclastic limestone with Orbitolina, annelids, Alguae, in association with Favusella washitensis, late Albian, platform deposit (sample $80 \mathrm{E} 6, \times 11$ ). (F) Fine-grained limestone with numerous sponge spicules and rare Pithonella, late Albian, slope or basin deposit (sample $80 \mathrm{E} 1, \times 16$ ). 


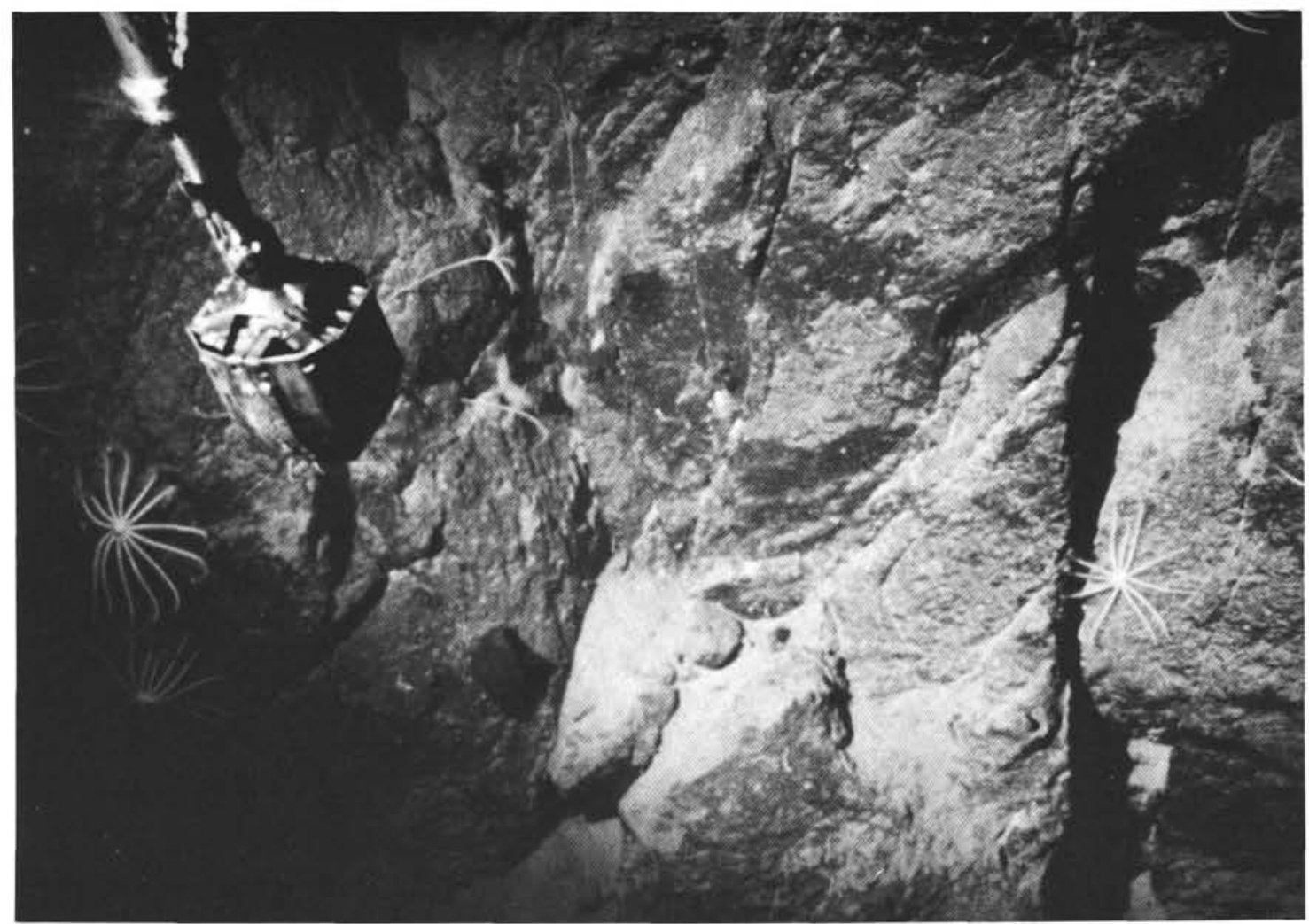

A

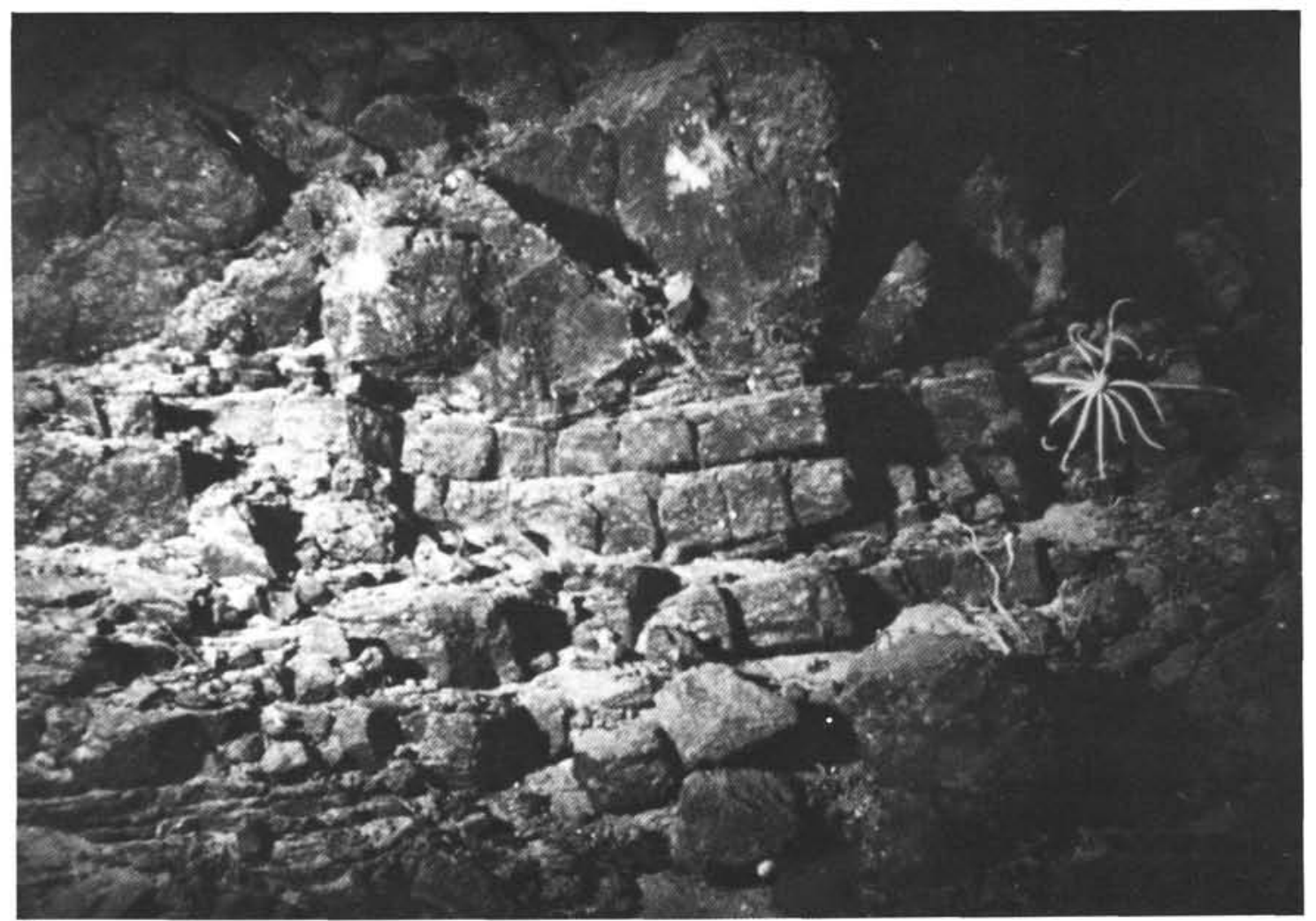

B

Figure 6. Photographs of the seafloor showing outcrops of Mesozoic rocks. (A) Fine-grained limestone of Portlandian to Berriasian age (sample 76 E 3; dive 76; depth, 2685 m). (B) Early Cretaceous sandstone (dive 83; depth, 2595 m). 


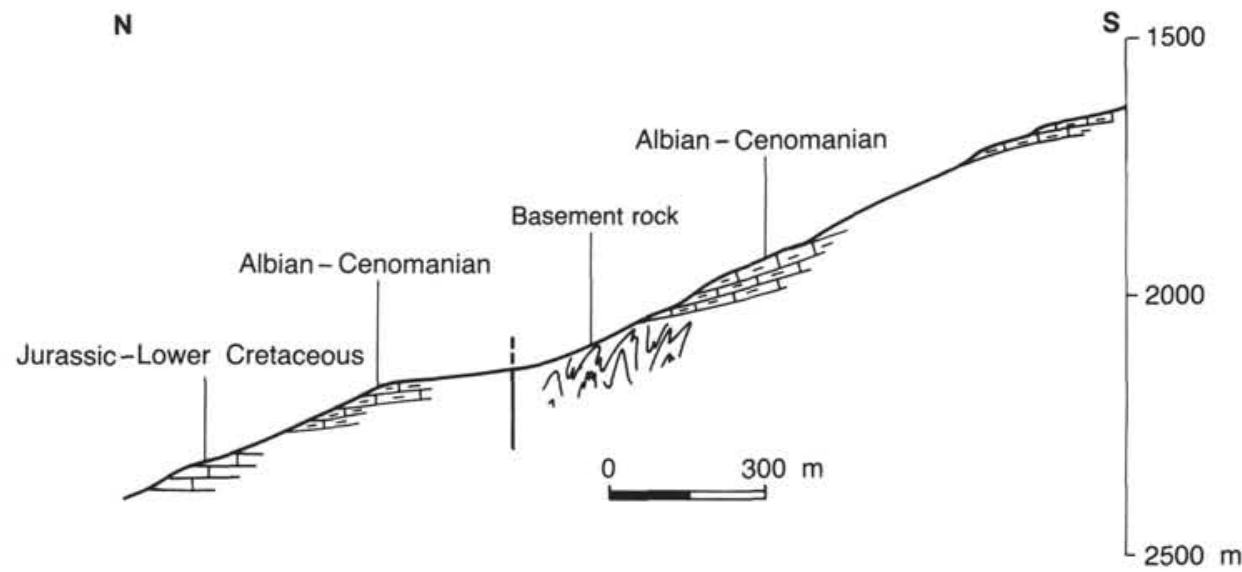

Figure 7. Geological cross section at dive-site 3. Albian-Cenomanian sediments rest unconformably on the basement in the upper part of the cross section and on the Jurassic and Early Cretaceous in the lower part (post-rift unconformity). Location of site shown in Figure 3.

ume) is late Aptian, pre-Albian on the north Galicia margin (this paper), and early Albian on the Goban Spur margin (de Graciansky, Poag et al., 1985). Actually, rifting ended and seafloor spreading started at approximately the same time north and west of Galicia.

Timing of the first stages of rifting is more questionable. In the Aquitaine Basin, west of the Bay of Biscay, episodes of rifting occurred during the Triassic and Late Jurassic-Early Cretaceous (BRGM et al., 1974; Brunet, 1984). On the Armorican margin as well as on the north and west Galicia margins, only the Early Cretaceous stage of this rifting is documented. In the Ortegal Spur area, detrital influx into sediments began during the Berriasian (Fig. 4) and can be related to the early break-up of the Jurassic carbonate platform. Finally, this segment of the Iberian margin underwent the same evolution as did the adjacent and conjugate margins.

\section{Orientation of Rift Segments and Kinematics}

We assume that $\mathrm{N} 120^{\circ}$ represents the direction of the initial rift along the north Spanish margin, whereas N70 ${ }^{\circ}$ and northsouth directions correspond to the rift orientation of Ortegal Spur and west Galicia margins, respectively (Fig. 11).

Actually, the Iberian plate has not moved along a simple trajectory with respect to the European plate during and after rifting. The Mesozoic kinematics of Iberia can be divided into at least two successive rotations. An initial southwestward divergent motion was followed by strike-slip motion along the north Pyrenean transform zone (Malod, 1982; Boillot, 1984). However, the timing of this kinematic change remains uncertain. According to Olivet et al. (1984), the southeastward motion started during rifting, whereas Boillot (1984) proposed that this motion began just after rifting, when seafloor spreading started. In any case, both west Galicia and north Galicia rifts, respectively striking north-south and $\mathrm{N} 70^{\circ}$, underwent divergent motion during the two kinematic stages (Fig. 11).

\section{SUMMARY AND CONCLUSIONS}

Rock sampling and structural observations from the submersible Cyana, dredge hauls, and Sea Beam mapping on the north Galicia slope allowed us to establish the stratigraphy and the fault pattern of that margin. According to these data, the Mesozoic Ortegal Spur and adjacent margins evolved similarly. The main rifting occurred during the Early Cretaceous and ended before the Albian, when seafloor spreading began to the west and to the north of the Iberian Peninsula. However, tectonics and subsidence are peculiar to the Ortegal Spur region. The ori- entation of the Mesozoic rift was $\mathrm{N} 70^{\circ}$, whereas it was northsouth on the west Galicia margin and $\mathrm{N} 120^{\circ}$ on the north Spanish margin. The syn-rift sediments were deposited in shallowwater conditions, whereas the sediments of the same age to the west of Galicia and to the north of Asturias suggest a deepening rift. This difference probably relates to a lesser degree of thinning of the continental crust below the north Galicia margin, whereas the stretching of the crust induced rapid deepening and subsidence on adjacent margins. Clearly, the present slope of Ortegal Spur, above $3000 \mathrm{~m}$ water depth, belonged to the upper part of a passive margin during the Mesozoic.

\section{ACKNOWLEDGMENTS}

We thank A. Meyer and anonymous reviewers for useful comments on the first draft of this paper. The Cybere Leg was supported by CNEXO and CNRS (ATP GGO grants 179 and 258). We also thank the Cyana and Suroick crews for their close cooperation.

\section{REFERENCES}

Anton, P. C., and Vegas, R., 1980. Le réseau de linéaments observés à partir des images Landsat et son application à un modèle géodynamique de la péninsule ibérique. In BRGM (Ed.), 26th International Geological Congress: Paris, 2:809 (Abstract).

Arthaud, F., and Matte, P., 1975. Les décrochements tardi-hercyniens du Sud Ouest de l'Europe. Géométrie et essai de reconstitution des conditions de la déformation. Tectonophysics, 25:139-171.

Boillot, G., 1984. Some remarks on the continental margins in the Aquitaine and French Pyrenees. Geol. Mag., 121(5):407-412.

Boillot, G., 1986. Comparison between the Galicia and Aquitaine margins. Tectonophysics, 129:243-255.

Boillot, G., Dupeuble, P. A., Hennequin-Marchand, I., Lamboy, M., and Lepretre, J. P., 1973. Carte géologique du plateau continental nord espagnol entre le canyon de Capbreton et le canyon d'Aviles. Bull. Soc. Géol. Fr., 7(XV):367-391.

Boillot, G., Dupeuble, P. A., and Malod, J. A., 1979. Subduction and tectonics on the continental margin off northern Spain. Mar. Geol., 32:53-70.

Boillot, G., Temime, D., Malod, J. A., et al., 1985. Exploration par submersible de la marge continentale du Nord Ouest de l'Espagne. Bull. Soc, Géol. Fr., 8(I):89-102.

BRGM, ELF-Re, ESSO-REP, SNAP, 1974. Géologie du bassin d'Aquitaine. BRGM (Ed.). 27 plates.

Brunet, M. F., 1984. Subsidence history of the Aquitaine basin determined from subsidence curves. Geol. Mag., 121:421-428.

Cottard, F., 1982. Mise en évidence par auto-corrélation optique et l'interprétation sur images spatiales de guides structuraux ayant présidé à la répartition des gîtes d'étain et de tungstène dans le Nord-Ouest de la Pénisule Ibérique. Bull. Soc. Géol. Fr., 7(XXIV):117-126. 
de Graciansky, P., Poag, C. W., et al., 1985. Init. Repts. DSDP, 80: Washington (U.S. Govt. Printing Office).

Deregnaucourt, D., and Boillot, G., 1982. Structure géologique du Golfe de Gascogne. Bull. B.R.G.M., 2(I):149-178.

Feuillée, P., and Rat, P., 1971. Structures et paleogéographies pyrenéocantabriques. In Technip (Ed.), Histoire Structurale du Golfe de Gascogne: Paris (Technip), V.I.1-V.1.48.

Grimaud, S., Boillot, G., Collette, B., Mauffret, A., Miles, P. R., and Roberts, D. B., 1982. Western extension of the Iberian-European plate boundary during the early Cenozoic (Pyrenean) convergence: a new model. Mar. Geol., 45:63-77.

Groupe Cybere, 1984. La Marge Déformée du Nord Ouest de l'Espagne. Résultats des Campagnes à la Mer, 29. Paris (CNEXO).

Lamboy, M., 1976. Géologie marine et sous marine du plateau continental au Nord Ouest de l'Espagne. Genèse des glauconies et des phosphates [Master's Thesis]. Université de Rouen, France.

Lamboy, M., and Dupeuble, P. A., 1975. Carte géologique du plateau continental nord ouest espagnol entre les canyons d'Aviles et la frontière portugaise. Bull. Soc. Géol. Fr., 7(XVII):442-461.

Malod, J. A., 1982. Comparaison de l'évoltion des marges continentales au Nord et au Sud de la Péninsule ibérique [Master's Thesis]. Mém. Sc. Terre Univ. Curie, Paris $\mathrm{N}^{\circ} 82-23$.

Malod, J. A., Boillot, G., et al., 1980. Campagne Cyadanois. 9-22 Juillet 1979. Résultats des campagnes à la mer, 20. Paris (CNEXO).

Malod, J. A., Boillot, G., Capdevila, R., Dupeuble, P. A., Lepvrier, C., Mascle, G., Muller, C., and Taugourdeau-Lantz, J., 1982. Subduction and tectonics on the continental margin off northern Spain: observations with the submersible Cyana. In J. K. Leggett (Ed.), Trenchforearc Geology. Geol. Soc. London, Spec. Publ. 10, 309-315.

Malod, J. A., Klitgord, K. D., and Schouten, H., 1984. Early motion of the plates around the northern Atlantic during Late Jurassic-Early Cretaceous rifting. Eos, 65(45):1100 (Abstract).

Martinez-Alvarez, J. A., 1974. Consideraciones sobre la posición geostructural de la Peninsula Ibérica. Bol. Geol. Minero., LXXXV(V): 513-517.
Montadert, L., de Charpal, O., Roberts, D., Guennoc, P., and Sibuet, J. C., 1979. Northeast Atlantic passive continental margin: rifting and subsidence processes. In Talwani, M., Hay, W., and Ryan, W. B. F. (Eds.), Deep Drilling Results in the Atlantic Ocean: Continental Margins and Paleoenvironments, M. Ewing Series 3: Washington (Am. Geophy. Union), 154-186.

Montadert, L., Roberts, D. G., et al., 1979. Init. Repts. DSDP, 48: Washington (U.S. Govt. Printing Office).

Olivet, J. L., Bonnin, J., Beuzard, P., and Auzende, J. M., 1984. Cinématique de l'Atlantique Nord et Central. Rapports Scientifiques et techniques 54: Paris (CNEXO).

Parga, J. R., 1969. Spätvariszische Bruchtsysteme im Hesperischen Massiv. Geol. Rundsch., 59:323-336.

Pujalte, V., 1981. Sedimentary succession and paleoenvironments within a fault-controlled basin: the "Wealden" of the Santander area, northern Spain. Sediment. Geol., 28:293-325.

Rat, P., Amiot, M., Feuillee, P., Floquet, M., Mathey, B., Pascal, A., Salomon, J., 1983. Vue sur le Cretacé basco-cantabrique et nordibérique: une marge et son arrière pays, ses environnements sédimentaires. Mém. Géol. Univ. Dijon, 9:177-180.

Sibuet, J. C., and Le Pichon, X., 1971. Structure gravimétrique du Golfe de Gascogne et le fossé marginal nord espagnol. In Technip (Ed.), Histoire Structurale du Golfe de Gascogne: Paris, VI.9.1-VI.9.18.

Sibuet, J.C., Ryan, W. B. F., et al., 1979. Init. Repts. DSDP, 47, Pt. 2: Washington (U.S. Govt. Printing Office).

Temime, D., 1984. Contribution à l'étude géologique de la marge au Nord Ouest de l'Espagne. Mém. Sc. Terre Univ. Curie, Paris, 84-26.

Vanney, J. R., Rojouan, F., Temime, D., Malod, J. A., et al., 1985. Observations géomorphologiques effectuées en plongées au Nord Ouest de la Péninsule ibérique. Bull. Soc. Géol. Fr., 8(I):153-159.

Wiedman, J., Kullmann, J., and Schonenberg, R., (Eds.), 1983. Subsidenz-Entwicklung im Kantabrishen Variszikum und an passiven Kontinentalrändern der Kreide. Teil 2-Kreide. N. Jb. Geol. Paläont. $A b h .$, Stuttgart, 165(1):1-183. 

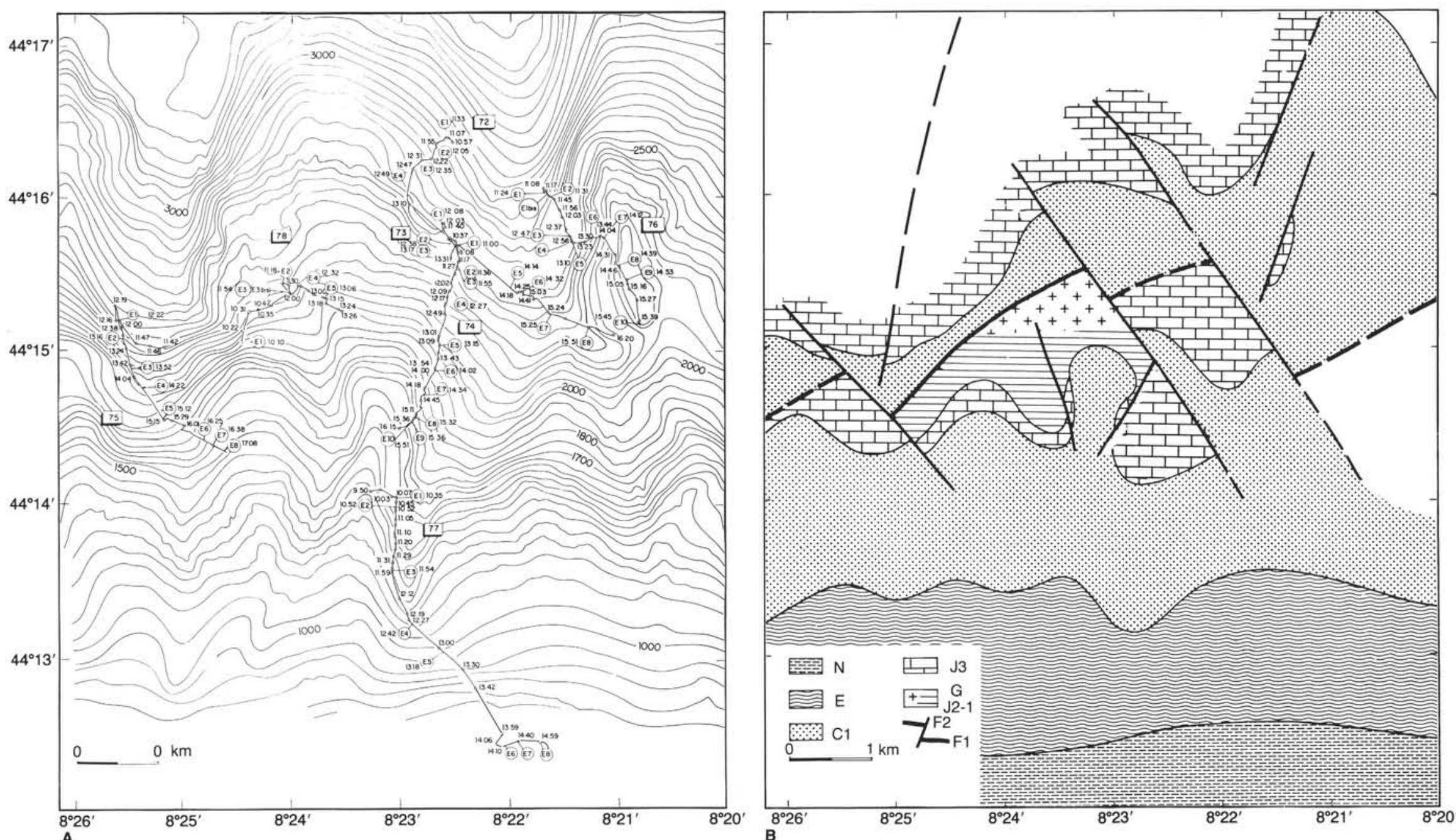

Figure 8. (A) Bathymetry and dive paths at site 2. Dive numbers in rectangles; sample numbers in circles. (B) Structural sketch of site $2 . \mathrm{N}=\mathrm{Neogene}, \mathrm{E}=$ late Eocene, $\mathrm{C} 1=\mathrm{Early} \mathrm{Cretaceous}$, $\mathrm{J} 3$ = Late Jurassic, J2-1 = Middle Jurassic, $\mathrm{G}=$ basement, F1 = probable normal fault of the former rift, F2 = probable transverse fault of the former rift. 


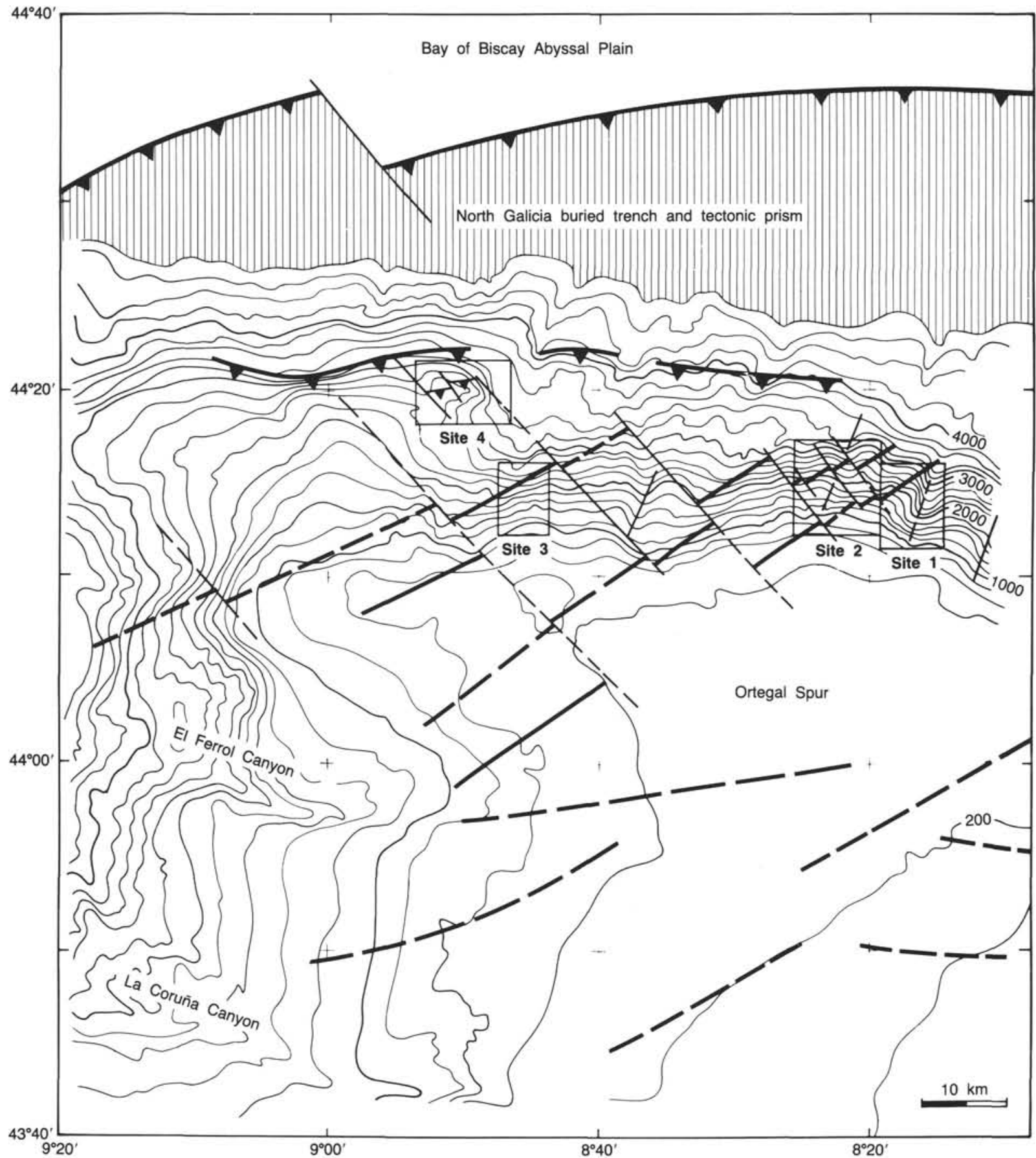

Figure 9. Tectonic sketch of Ortegal Spur. Main apparent west-southwest structures are linked to the rifting, and east-west structures of the deep margin are probably related to the extinct north Galicia subduction trench. Dive sites are marked. Fault locations on the shelf are after Lamboy and Dupeuble (1975), and the bathymetric contours are after Vanney et al. (1985). Bathymetric contours in meters; contour interval, $200 \mathrm{~m}$. 
Unit 1

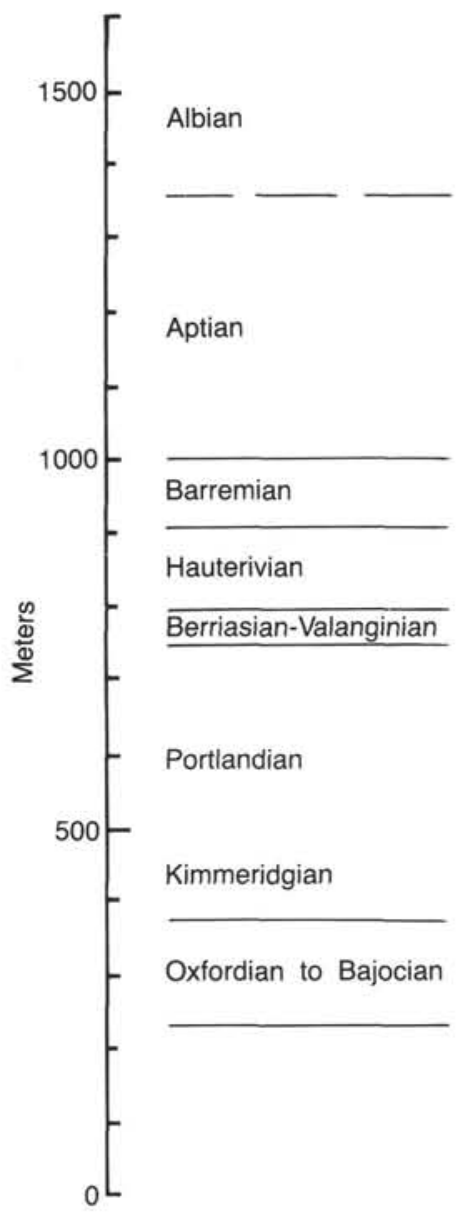

Unit 2

Unit 3

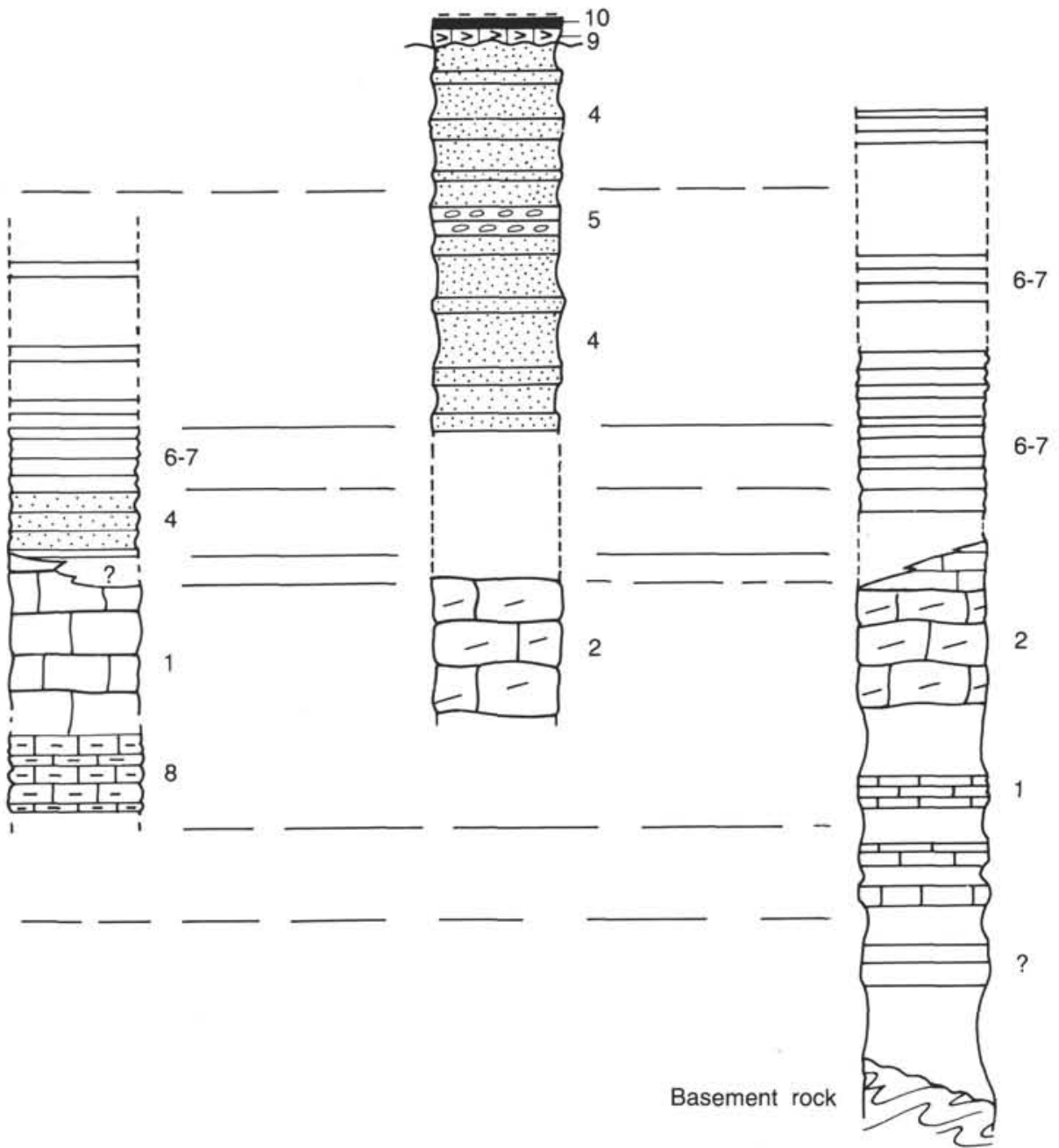

Figure 10. Stratigraphic log on the Le Danois Bank (north Spanish margin). $1=$ massive limestone, $2=$ dolomitic limestone, $3=$ brecciated and gravelly limestone, $4=$ sandstone, $5=$ coarse sandstone and conglomerate, $6=$ silt, $7=$ shale, $8=$ marly limestone, $9=$ early Tertiary reefal limestone, 10 = Aquitanian limestone and Pliocene marl. After Malod et al. (1982). 


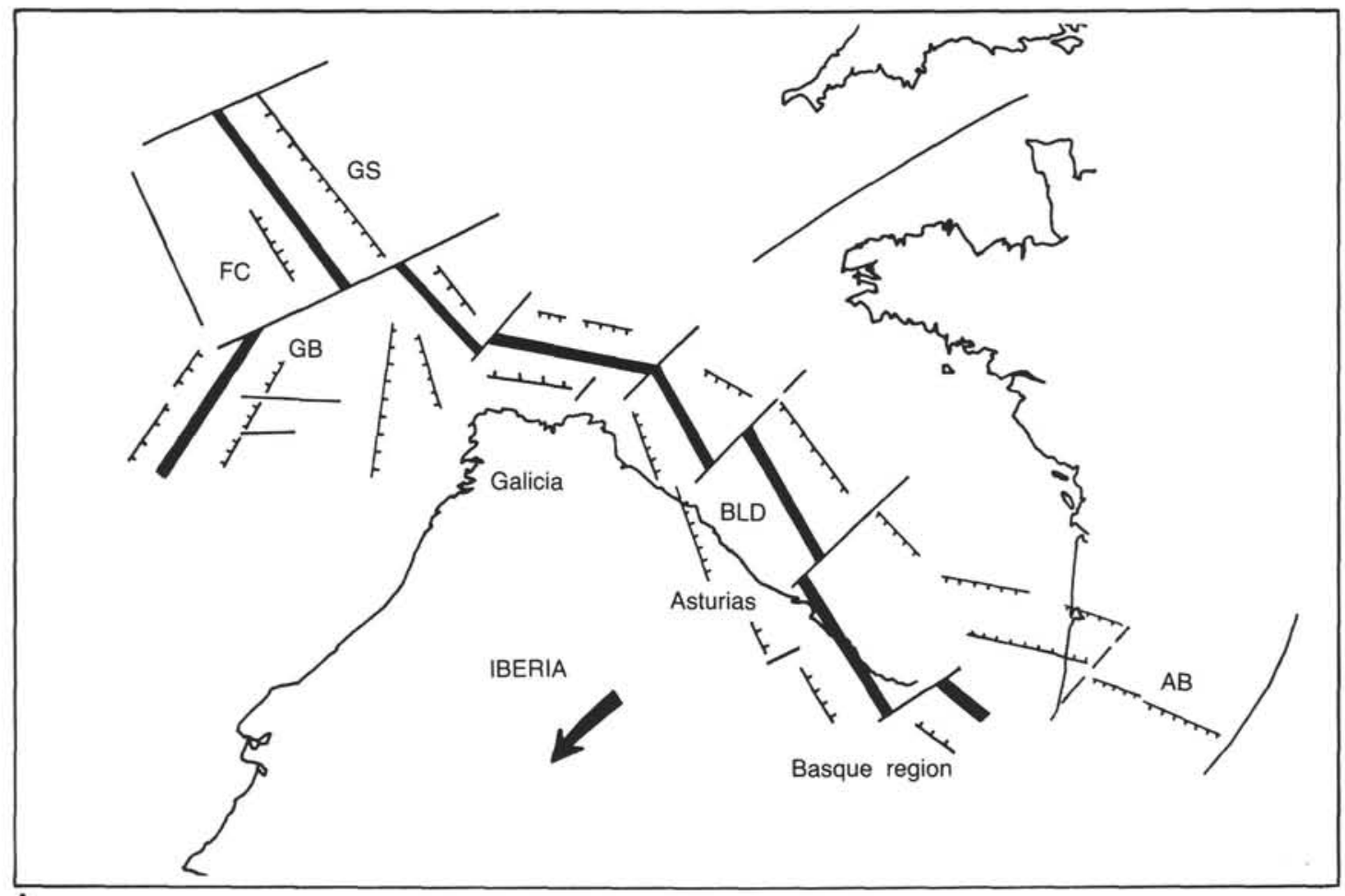

A

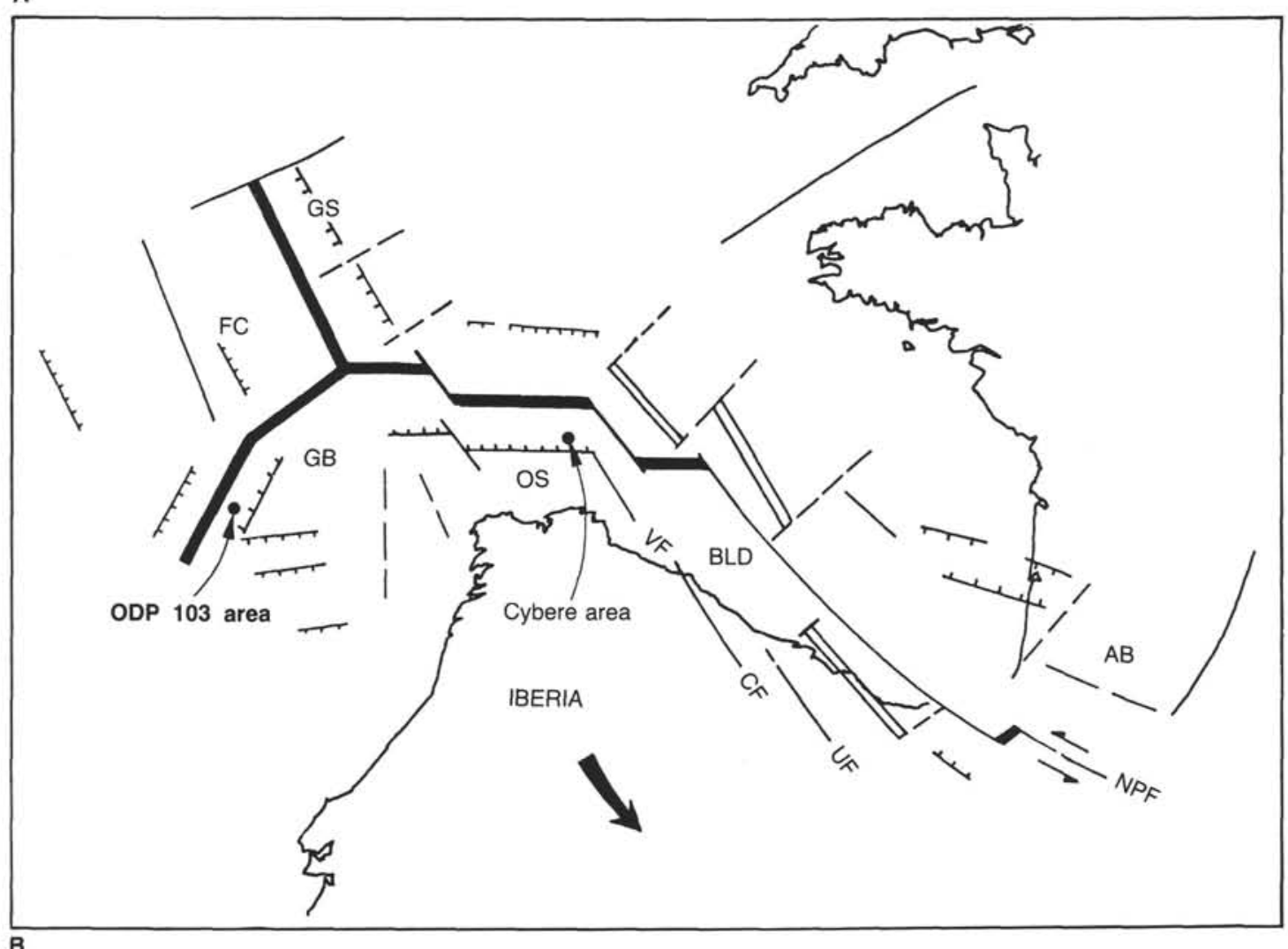

Figure 11. Diagram of the rift evolution north and west of the Iberian plate. (A) During a first phase, Iberia moved southwest with respect to Europe. Galicia margin stretched along a northeast direction. (B) During a second phase, Iberia moved southeast. The motion along the Pyrenean transform fault (NPF) resulted in the opening of the Bay of Biscay. At Ortegal Spur, the direction of the stretching became south-southeast. The axis of the former rift stage probably remains in the Armorican margin and in the Basque region. Arrows indicate the motion of Iberia with respect to Europe. $\mathrm{AB}=$ Aquitaine Basin, CF = Cantabrica fault, BLD = Le Danois Bank, FC = Flemish Cap, GB = Galicia Bank, GS = Goban Spur, NPF $=$ North Pyrenean fault, OS = Ortegal Spur, UF $=$ Urbiena fault, VF $=$ Vidio fault. 